\title{
Liriopesides B from Liriope spicata var. prolifera inhibits metastasis and induces apoptosis in A2780 human ovarian cancer cells
}

\author{
HAIZHONG YU ${ }^{1,2^{*}}$, HAIYAN WANG ${ }^{2 *}$, YOUPING YIN ${ }^{1}$ and ZHONGKANG WANG ${ }^{1}$ \\ ${ }^{1}$ College of Life Sciences, Chongqing University, Chongqing 400044; ${ }^{2}$ School of Food Science and Technology, \\ Hubei University of Arts and Science, Xiangyang, Hubei 441053, P.R. China
}

Received August 5, 2019; Accepted May 12, 2020

DOI: $10.3892 / \mathrm{mmr} .2020 .11256$

\begin{abstract}
Ovarian cancer is the most frequent cause of death among gynecological cancers. In the present study, the anti-cancer effect of liriopesides B, a steroidal saponin from Liriope spicata var. prolifera, against A2780 cells was investigated. Transwell chambers were adopted to assess its effect on cell invasion and chemotaxis abilities. Flow cytometry was used to analyze the cell cycle and apoptosis. Reverse transcription-quantitative PCR was employed to examine gene expression levels. Western blot analysis was performed to detect protein expression levels. Liriopesides B inhibited the invasion and chemotactic movement ability of A2780 cells in a dose-dependent manner. Furthermore, liriopesides B caused cell cycle arrest in A2780 cells at the G1 phase following incubation for 24, 48 and $72 \mathrm{~h}$. Hoechst 33258 staining indicated that, following incubation for $48 \mathrm{~h}$, liriopesides B induced cell apoptosis in a dose-dependent manner. Flow cytometry verified that liriopesides B induced apoptosis in A2780 cells and induced late apoptosis in a dose-dependent manner. Furthermore, liriopesides B significantly increased the mRNA expression levels of E-CADHERIN, $p 21$ and $p 27$ and decreased the gene expression levels of $B C L-2$, which was consistent with its protein expression levels. In conclusion, liriopesides B possess anti-cancer properties, including inhibition of metastasis-associated behaviors, cell cycle arrest and induction of apoptosis. Therefore, liriopesides B may be considered as a candidate drug against ovarian cancer.
\end{abstract}

Correspondence to: Professor Zhongkang Wang, College of Life Sciences, Chongqing University, 174 Shazhengjie, Shapingba, Chongqing 400044, P.R. China

E-mail:w-zk@163.com

${ }^{*}$ Contributed equally

Key words: Liriope spicata var. prolifera, liriopesides B, A2780 cells, metastasis, cell cycle arrest, apoptosis

\section{Introduction}

Cancer is the second leading cause of death worldwide and nearly 1 in 6 deaths are due to it (1). According to the World Health Organization, $70.0 \%$ of deaths from cancer occur in low- and middle-income countries (1). As a serious malignant neoplasm, ovarian cancer is a relatively rare type of cancer, but it is the most frequent cause of death from gynecological cancer worldwide $(2,3)$. For instance, the number of new cases of ovarian cancer was $11.4 / 100,000$ females per year and the number of deaths was 7.0/100,000 per year in the USA based on cases and deaths between 2012 and 2016 (4). Furthermore, it has a poor prognosis, with the 5 -year survival rate being only $40 \%$ in the UK (5). Thus, an increasing amount of anti-tumor drugs from plants have been studied due to their affordability and relatively fewer side effects (6).

Radix ophiopogonis, recorded as a traditional Chinese medicine in the Pharmacopoeia of the China (2015 edition) (7), consists of the roots from three botanical sources, namely Liriope spicata var. prolifera, Ophiopogon japonicus and Liriope muscari, which are widely distributed in East Asia, particularly in China (mainly in the Provinces Hubei, Zhejiang, Sichuan and Fujian) (8). Steroidal saponins are among the major components of radix ophiopogonis and 72 steroidal saponins have so far been isolated and identified (8-14). Studies have indicated that the steroidal saponins of radix ophiopogonis possess a marked anti-cancer activity. Among 15 types of steroidal saponins isolated from the tuberous roots of Ophiopogon japonicus, 5 different saponins were cytotoxic to all tested cell lines (HepG2, HLE, BEL7402, BEL7403 and $\mathrm{HeLa}$ (9). Ophiopogonin B induces autophagy in non-small cell lung cancer cells by inhibiting the PI3K/Akt signaling pathway way (10) and autophagy and apoptosis of colon cancer cells by activating the JNK/c-Jun signaling pathway (11), sensitization to tumor necrosis factor superfamily member 10 -induced apoptosis (12) and suppression of the metastasis and angiogenesis of A549 cells by inhibiting the EPH receptor A2/Akt signaling pathway (13). Ophiopogonin D inhibits the proliferation and leads to chemosensitization of human lung cancer cells $(12,14)$. Ophiopogonin D induces apoptosis in androgen-independent human prostate cancer cells (15).DT-13 inhibits breast cancercell migration via modulation of procollagen-lysine, 2-oxoglutarate 
5-dioxygenase 2 in the adipocyte microenvironment (16). DT-13 inhibits the proliferation of colorectal cancer cells via the glycolytic metabolism and the adenosine monophosphate-activated protein kinase/mTOR signaling pathway (17). DT-13 inhibits the proliferation and metastasis of human prostate cancer cells by blocking the PI3K/Akt pathway (18). DT-13 is also able to induce autophagy and potentiate the anti-cancer effect of nutrient deprivation (19) and suppress cell adhesion and invasion by inhibiting matrix metalloproteinase-2/9 (20) and downregulating $\mathrm{C}-\mathrm{C}$ motif chemokine receptor type 5 (CCR5) and vascular endothelial growth factor in MDA-MB-435 cells (21). DT-13 inhibits gastric cancer cell migration via downregulation of the CCR5-C-C motif chemokine ligand 5 axis (22) and attenuates human lung cancer metastasis via regulating non-muscle myosin IIA (NMIIA) activity under hypoxic conditions (23). The combination of DT-13 and topotecan synergistically inhibits human gastric cancer (24) via MIIA-induced endocytosis of epidermal growth factor receptor (EGFR) (25) and aerobic glycolysis via the NMIIA/EGFR/hexokinase II axis (26), and potentiates the sensitivity of gastric cancer cells to topotecan by inducing cell cycle arrest (24). DT-13 synergistically enhances vinorelbine-mediated mitotic arrest through inhibition of the forkhead box M1-BICD cargo adaptor 2 axis in non-small cell lung cancer cells (27) and activation of the ERK signaling pathway in NCI-H1299 cells (28).

However, the anti-cancer activities of steroidal saponins on A2780 cells and their mechanisms of action remain to be elucidated. A previous study by our group reported that liriopesides B [chemical structure drawn with chemdraw 14.0 (CambridgeSoft) and presented in Fig. 1], one of the steroidal saponins from L. spicata var. prolifera in Hubei, inhibits proliferation and induced cell differentiation by decreasing cancer antigen 125 levels and alkaline phosphatase (AKP) activity in A2780 cells (29). Therefore, the same concentration of liriopesides B according to its $\mathrm{IC}_{50}$ value in A2780 cells for the same treatment time of $48 \mathrm{~h}$ (29) was selected to explore the effects of liriopesides B on metastatic activity, cell cycle arrest and apoptosis of A2780 cells in the present study.

\section{Materials and methods}

Materials. A2780 ovarian cancer cells were obtained from the China Center for Type Culture Collection. Dulbecco's modified Eagle's medium (DMEM) was provided by GE Healthcare. Fetal bovine serum (FBS) was from Gibco (Thermo Fisher Scientific, Inc.). Dimethyl sulfoxide (DMSO) was from Amresco, LLC. Crystal Violet, Hoechst 33258 kits and Annexin V-FITC/PI Apoptosis Detection kit were purchased from Wuhan Hualianke Biotechnology Co., Ltd. Fibronectin was from Sigma-Aldrich (Merck KGaA). Matrigel was obtained from BD Biosciences. Liriopesides B isolated from the tuberous root of Liriope spicata var. prolifera was identified by nuclear magnetic resonance spectroscopy with its purity beyond $95 \%$ (Shanghai Yuanye BioTechnology Co., Ltd.) and 0.1\% DMSO was used as a solvent (20). The other chemicals and solvents used were all of the highest purity grade available.

Cell cultivation. A2780 cells were cultivated with DMEM containing $10 \% \mathrm{FBS}, 100 \mu \mathrm{g} / \mathrm{ml}$ streptomycin and $100 \mathrm{IU} / \mathrm{ml}$ penicillin at $37^{\circ} \mathrm{C}$ in a humidified atmosphere with $5 \% \mathrm{CO}_{2}$.
Cell invasion assay. The invasive abilities of A2780 cells were assessed in Transwell chambers ( $8-\mu \mathrm{m}$ pore size; Corning Inc.) using a slightly modified method based on that reported by Nizamutdinova et al (30). Cells were treated with different concentrations of liriopesides $\mathrm{B}\left(0,1 \mathrm{xIC}_{50}, 5 \mathrm{xIC}_{50}\right.$ and $\left.10 \mathrm{xIC} \mathrm{IC}_{50}\right)$ in serum-free culture medium for $24 \mathrm{~h}$. Prior to seeding the cells, a 24-well plate and Transwell chambers were filled with $1 \mathrm{X}$ PBS to moisten the chambers for $5 \mathrm{~min}$. The upper side of the filter membrane of the Transwell chamber was coated with $500 \mathrm{mg} / \mathrm{l}$ fibronectin $(10 \mu \mathrm{l})$, while the lower side of the filter membrane was coated with $500 \mathrm{mg} / \mathrm{l}$ Matrigel $(10 \mu \mathrm{l})$ and dried for $30 \mathrm{~min}$ at $37^{\circ} \mathrm{C}$. Cells were suspended and seeded into the upper chamber in serum-free media at a density of $1 \times 10^{5}$ cells in $0.5 \mathrm{ml}$ per chamber. The lower chamber of the 24-well plate was filled with $0.75 \mathrm{ml}$ DMEM containing $10 \%$ FBS. After $48 \mathrm{~h}$ of incubation at $37^{\circ} \mathrm{C}$, cells that had transgressed through the lower side of the membrane were fixed with $1 \mathrm{ml} 4 \%$ formaldehyde for $10 \mathrm{~min}$ at room temperature, the media was discarded and cells were washed with $1 \mathrm{X}$ PBS once. Subsequently, $1 \mathrm{ml} 0.5 \%$ crystal violet solution was added to stain the cells for $30 \mathrm{~min}$ at room temperature, following which the cells were washed with 1X PBS three times. Cells that had not migrated through the membrane were removed with cotton swabs. The number of cells in each visual field (five fields were examined) were counted and a routine light microscope (IX53; Olympus Corporation) was used to capture typical images (magnification, x400). The rate of invasion was calculated as follows: Invasion rate=(invaded cells in treatment group/invaded cells in control group) $\mathrm{x} 100 \%$.

Cell chemotaxis assay. The chemotactic movement experiment of A2780 cells was performed in Transwell chambers using a slightly modified method based on that reported by Nizamutdinova et al (30). A2780 cells in the absence or presence of liriopesides $\mathrm{B}\left(1 \mathrm{xIC}_{50}, 5 \mathrm{xIC}_{50}\right.$ and $\left.10 \mathrm{xIC}_{50}\right)$ were cultivated in serum-free culture medium for $24 \mathrm{~h}$. Prior to seeding the cells, a 24-well plate and the Transwell chambers were filled with $1 \mathrm{X}$ PBS to moisten the chambers for $5 \mathrm{~min}$. Cells were suspended in DMEM with $1 \%$ FBS, counted and seeded into the chambers at a density of $1 \times 10^{5}$ cells in $0.5 \mathrm{ml}$ per chamber. The lower 24-well plate was filled with $0.75 \mathrm{ml}$ DMEM containing $10 \%$ FBS. After incubation at $37^{\circ} \mathrm{C}$ for $48 \mathrm{~h}, 1 \mathrm{ml} 4 \%$ formaldehyde per well was added to fix the cells for $10 \mathrm{~min}$ at room temperature. Subsequently, the media was discarded, the cells were washed with $1 \mathrm{X}$ PBS once and $1 \mathrm{ml} 0.5 \%$ crystal violet solution was then added to stain the cells for $30 \mathrm{~min}$ at room temperature, followed by washing with $1 \mathrm{X}$ PBS three times and drying. Cells without chemotaxis on the upper side of the filter were removed using cotton swabs. The number of cells in each visual field (five fields were examined) were counted and a routine light microscope (IX53; Olympus Corporation) was used to capture typical images (magnification, $\mathrm{x} 400)$. The rate of chemotaxis was calculated as follows: Chemotaxis rate $=$ (chemotaxis cells in the treatment group/chemotaxis cells in the control group) $\mathrm{x} 100 \%$.

Cell cycle analysis. Cell cycle analysis was performed as reported previously with certain modifications (31). Aftertreatment for 24,48 and $72 \mathrm{~h}$ with the indicated concentrations of liriopesides $\mathrm{B}\left(0,1 \mathrm{xIC}_{50}\right.$ and $\left.10 \mathrm{xIC}_{50}\right), \mathrm{A} 2780$ cells were fixed in ethyl alcohol and then kept overnight at $-20^{\circ} \mathrm{C}$. 
Table I. Sequences of primers for quantitative PCR.

\begin{tabular}{ll}
\hline Gene & \multicolumn{1}{c}{ Primer sequence } \\
\hline E-CADHERIN & F: 5'-CACCCTGGCTTTGACG-3' \\
& R: 3'-TAGGCTGTCCTTTGTCG-5' \\
BCL-2 & F: 5'-GGGAGGATTGTGGCCTTCTT-3' \\
& R: 3'-TCATCCACAGGGCGATGTT-5' \\
p21 & F: 5'-CTAATCCGCCCACAGG-3' \\
& R: 3'-TGAGACTAAGGCAGAAGATG-5' \\
p27 & F: 5'-GCTTGCCCGAGTTCTA-3' \\
& R: 3'-TCCCGCTGACATCCTG-5' \\
GAPDH & F: 5'-CCACTCCTCCACCTTTG-3' \\
& R: 3'-CACCACCCTGTTGCTGT-5'
\end{tabular}

F, forward; R, reverse; Bp, base pairs.

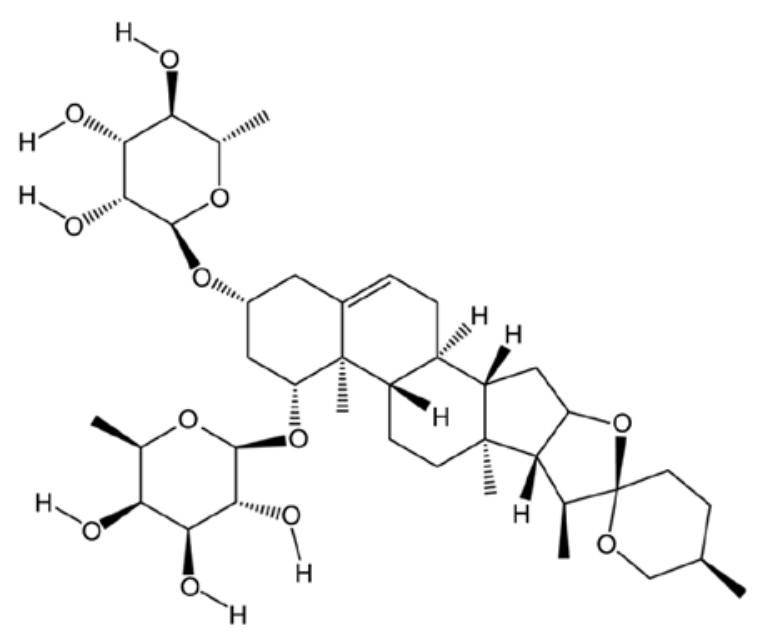

Figure 1. Chemical structure of liriopesides B.

Cells were washed twice with cold PBS. After incubation with $1 \mathrm{mg} / \mathrm{ml}$ RNase A (100 $\mu \mathrm{l}$; purchased from Thermo Fisher Scientific, Inc.) for $30 \mathrm{~min}$ at $37^{\circ} \mathrm{C}$, cells were stained with $400 \mu 150 \mu \mathrm{g} / \mathrm{ml}$ propidium iodide at $25^{\circ} \mathrm{C}$ in the dark for 20 min and analyzed with a flow cytometer (FC500 MCL; Beckman Coulter, Inc.) and ModFit LT2.0 (Verity Software House) was used to analysis the flow cytometry results.

Hoechst 33258 staining. After incubation in the absence or presence of indicated concentrations of liriopesides $\mathrm{B}\left(1 \mathrm{xIC}_{50}\right.$ and $5 \mathrm{xIC}{ }_{50}$ ) for $48 \mathrm{~h}$, cells were washed with PBS three times and fixed with $4 \%$ paraformaldehyde for $15 \mathrm{~min}$ at room temperature. Cells were then washed with PBS twice and stained for $5 \mathrm{~min}$ using $200 \mu 1$ Hoechst 33258 at room temperature. After washing five times with PBS, cellular nuclear staining was examined at $460 \mathrm{~nm}$ under a fluorescence microscope (TS100-F; Nikon Corporation; magnification, $\mathrm{x} 400$ ). The evenly distributed cells were randomly chosen for image capture.

Discrimination between early and late apoptosis. Discrimination between early and late apoptosis was performed as reported previously with certain modifications (32). Cells were incubated for 24,48 or $72 \mathrm{~h}$ with or without different concentrations of liriopesides $\mathrm{B}\left(1 \mathrm{xIC}_{50}\right.$ and $\left.10 \times \mathrm{IC}_{50}\right)$. Adherent and floating cells were harvested and washed twice with PBS, and then suspended in $200 \mu \mathrm{l}$ of $1 \mathrm{X}$ Binding Buffer, to which $10 \mu \mathrm{l}$ Annexin V-FITC and $10 \mu \mathrm{l}$ propidium iodide were added. After the cells were gently vortexed and incubated for $30 \mathrm{~min}$ in the dark, $300 \mu \mathrm{l}$ of $1 \mathrm{X}$ Binding Buffer was added. The fluorescence of the cells was detected with a flow cytometer (FC500 MCL; Beckman Coulter, Inc.) and CXP Analysis 2.0 (Beckman Coulter, Inc.) was used to analysis the flow cytometry results.

Reverse transcription-quantitative PCR (RT-qPCR). Gene expression levels were assessed as reported previously with certain modifications (32). Relative quantification of gene expression was performed by the $2^{-\Delta \Delta \mathrm{Cq}}$ method based on $\mathrm{Ct}$ values for both target genes (E-CADHERIN, BCL-2,p21 and p27) and reference gene $(G A P D H)(33)$. Cells were incubated for $48 \mathrm{~h}$ in the absence or presence of liriopesides $\mathrm{B}$ at different concentrations $\left(1 \mathrm{xIC}_{50}\right.$, $5 x \mathrm{IC}_{50}$ or $\left.10 x \mathrm{IC}_{50}\right)$. Total RNA was extracted using TRIzol reagent (Invitrogen; Thermo Fisher Scientific, Inc.) and were reverse transcribed into cDNA by using a reverse transcription kit (Takara Biotechnology Co., Ltd). The $20 \mu \mathrm{l}$ reaction system, including the total RNA, 5X reaction buffer, Oligo DT18 primer, dNTP Mix, RiboLock RNase Inhibitor, RevertAid M-MuLV RT and DNase-free $\mathrm{ddH}_{2} \mathrm{O}$, was prepared and the reverse transcription was performed as the follows: $42^{\circ} \mathrm{C} 60 \mathrm{~min}, 70^{\circ} \mathrm{C} 15 \mathrm{~min}$ then hold at $16^{\circ} \mathrm{C}$. The SYBR Green Real Time PCR Master Mix (Kapa Biosystems; Roche Diagnostics) was used to amplify the resulting cDNA samples with the Real-Time PCR Detection System (Bio-Rad Laboratories, Inc.). The amplification parameters were as follows: $95^{\circ} \mathrm{C}$ for $3 \mathrm{~min} ; 39$ cycles of $95^{\circ} \mathrm{C}$ for $5 \mathrm{sec}$, $56^{\circ} \mathrm{C}$ for $10 \mathrm{sec}$ and $72^{\circ} \mathrm{C}$ for $25 \mathrm{sec}$, and then $65^{\circ} \mathrm{C}$ for $5 \mathrm{sec}$ and $95^{\circ} \mathrm{C}$ for $50 \mathrm{sec}$. The primer sequences used were designed with Primer Premier v6.24 (Premier Biosoft International), except for $B C L-2$ (34), and they are listed in Table I.

Western blot analysis. Protein expression levels were assessed as previously described by Sun et al (35) with certain modifications. A2780 cells treated with or without liriopesides B $\left(1 \mathrm{xIC}_{50}, 5 \mathrm{xIC}_{50}\right.$ and $\left.10 \mathrm{xIC} \mathrm{I}_{50}\right)$ for $48 \mathrm{~h}$ were lysed in lysis buffer 
A
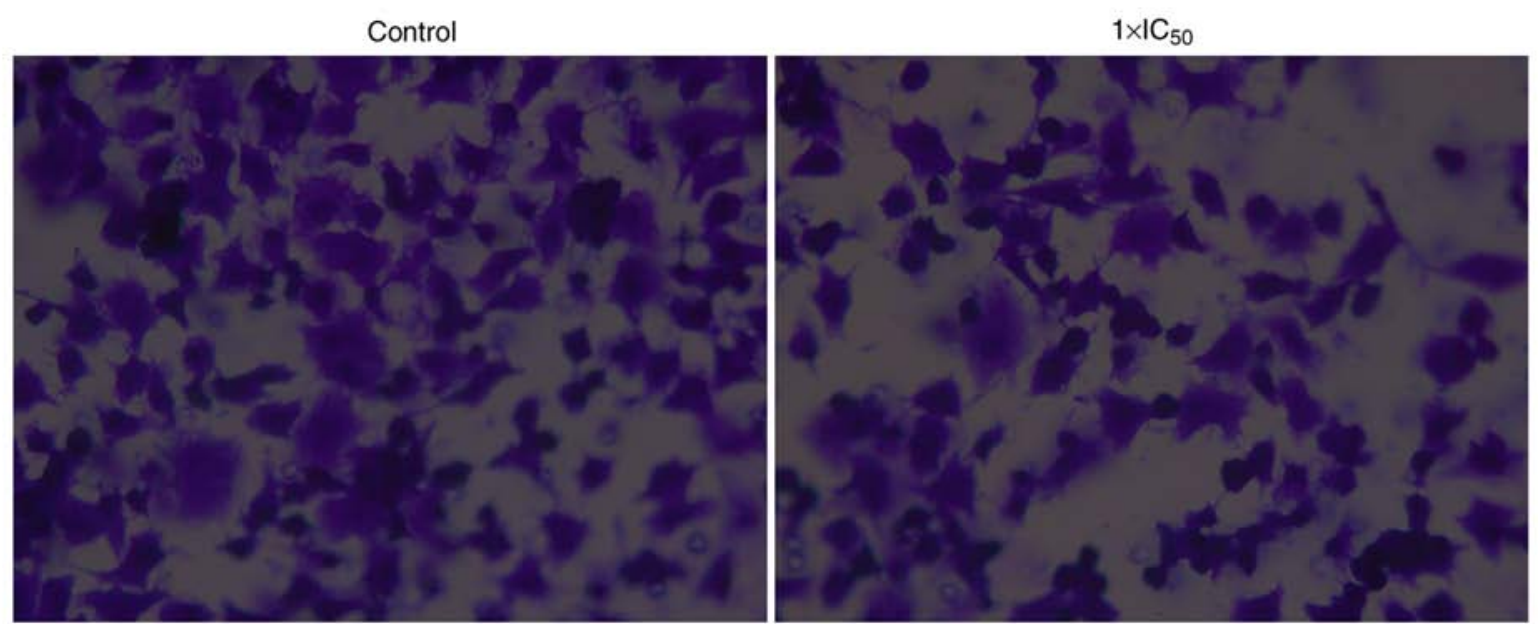

$5 \times \mathrm{IC}_{50}$

$10 \times \mathrm{IC}_{50}$
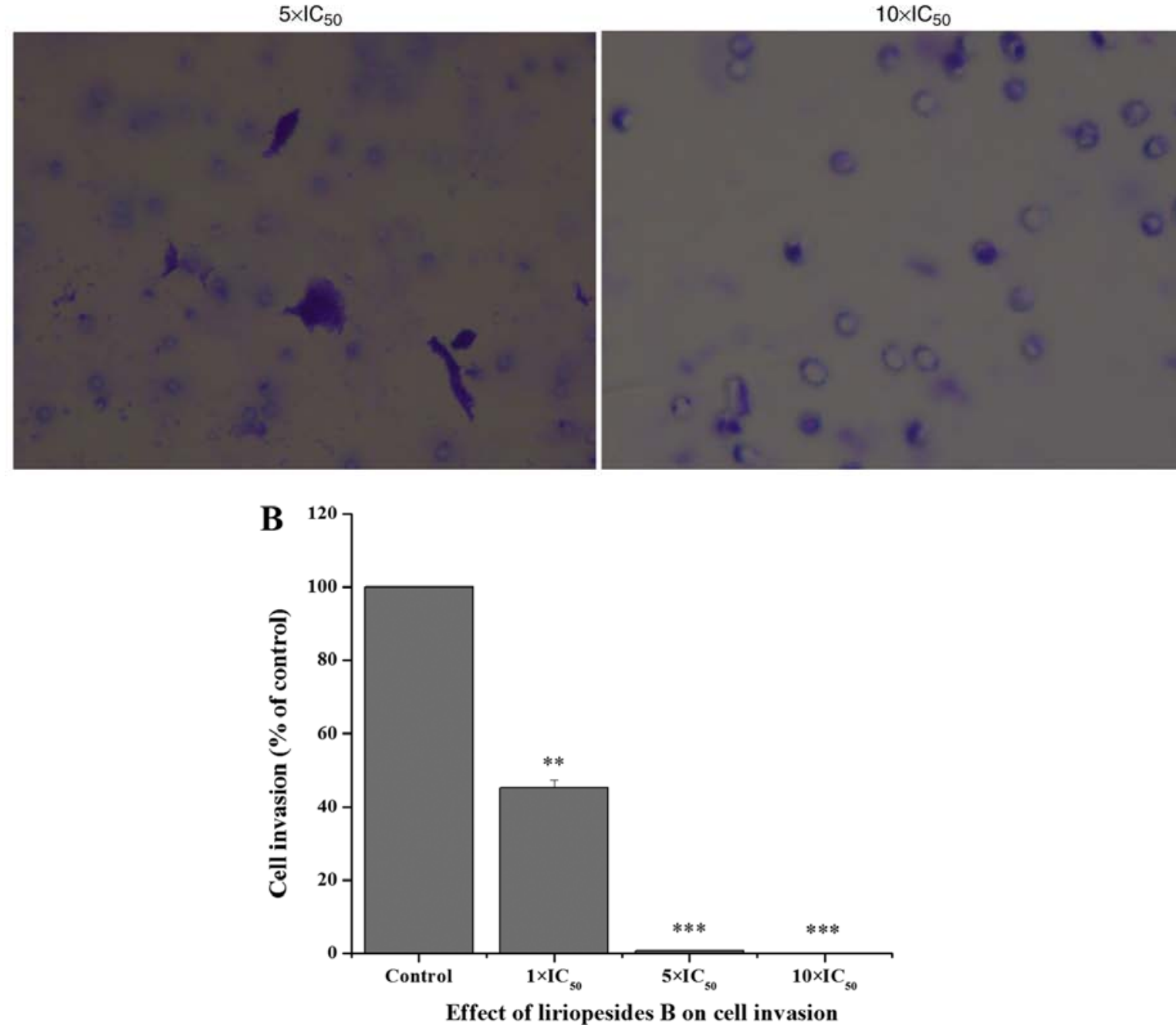

Figure 2. Effect of liriopesides B on the invasive ability of A2780 cells. In a Transwell assay, cells were treated with liriopesides B for $48 \mathrm{~h}$. (A) Representative images of invaded cells (magnification, $\mathrm{x} 400$ ). (B) Cell invasion ability was quantified by counting the invaded cells in the independent experiments. All values are expressed as the mean \pm standard deviation of triplicates (one-way analysis of variance). ${ }^{* *} \mathrm{P}<0.01,{ }^{* * *} \mathrm{P}<0.001$ vs. control group.

(Cell lysate HR2005, Wuhan Hualianke Biotechnology Co., Ltd.). The protein in the lysates was then quantified according to a BCA protein concentration test kit (HR2006, Wuhan Hualianke Biotechnology Co., Ltd.), and then separated by SDS-PAGE on a $12 \%$ gel (10 $\mu \mathrm{g}$ protein per lane), transferred onto a polyvinylidene difluoride membrane and blocked with $5 \%$ skimmed milk powder overnight at $4^{\circ} \mathrm{C}$. Membranes were then immunoblotted with antibodies at $4^{\circ} \mathrm{C}$ overnight against E-cadherin (1:5,000; cat. no. ab133597; Abcam), Bcl-2 (1:1,000; cat. no. ab32124; Abcam), p21 (1:1,000; cat. no. ab109199; Abcam), p27 (1:1,000; cat. no. ab32034; Abcam) and GAPDH (1:1,000; cat. no. 2118; Cell Signaling Technology, Inc.) was used as an endogenous reference. HRP labeled Goat anti-rabbit IgG (1:10,000; cat. no. HR2031; Wuhan Hualianke 
A

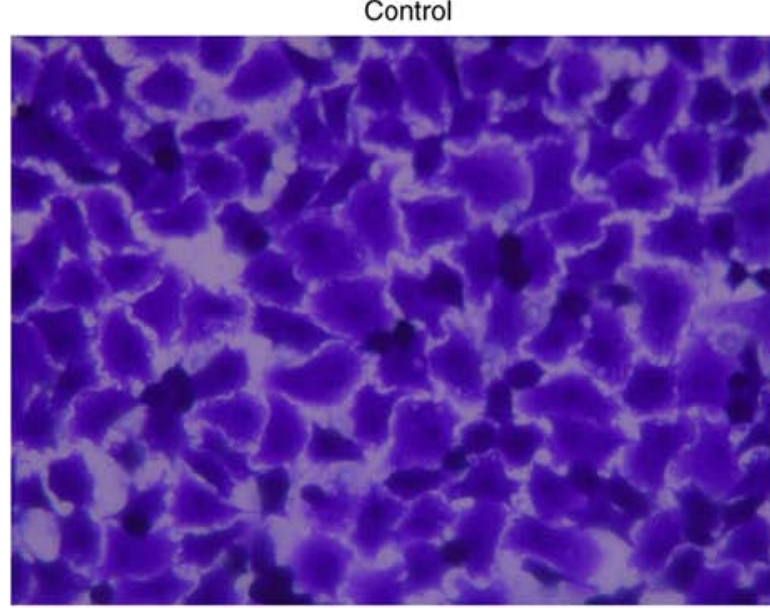

$5 \times \mid C_{50}$

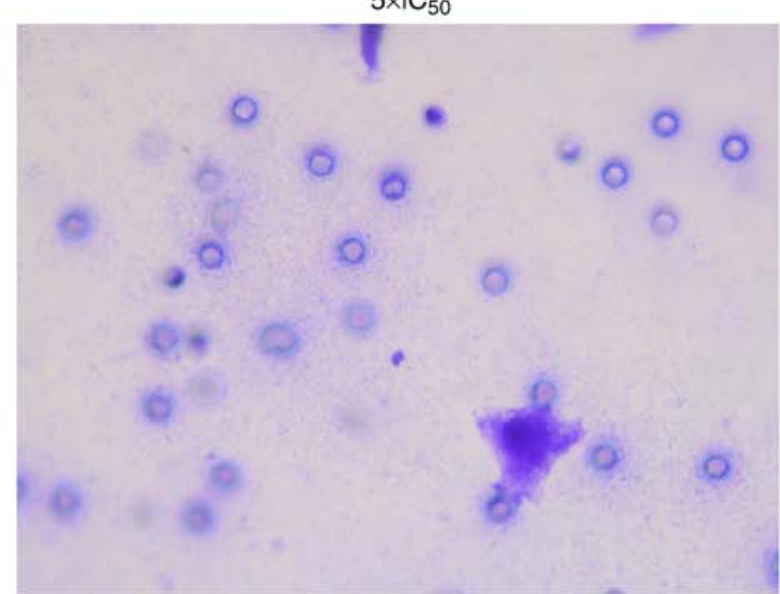

$1 \times \mid C_{50}$

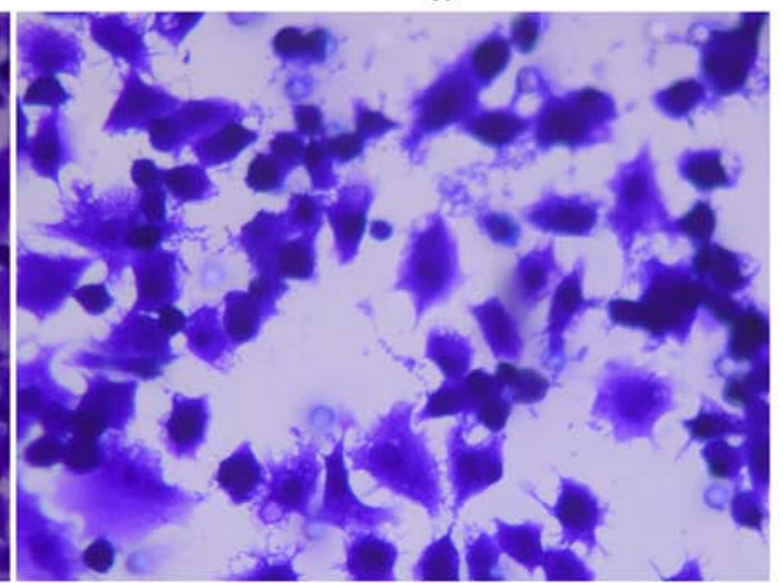

$10 \times 1 \mathrm{C}_{50}$

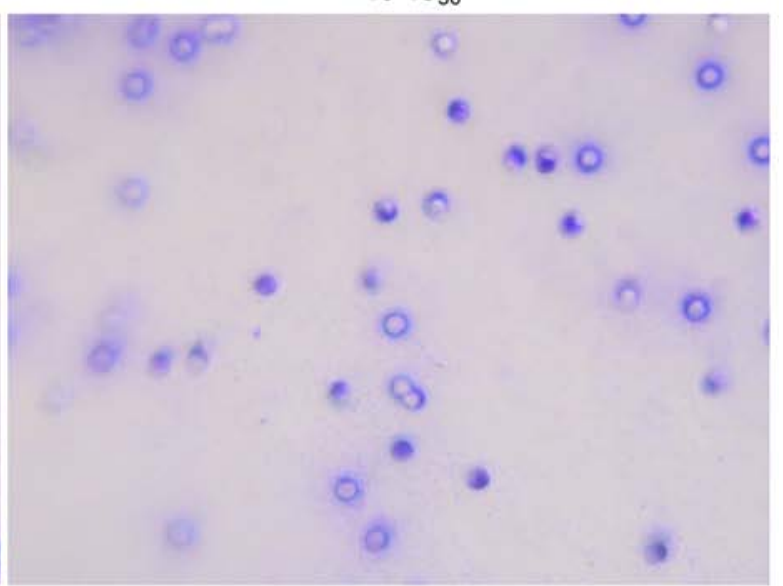

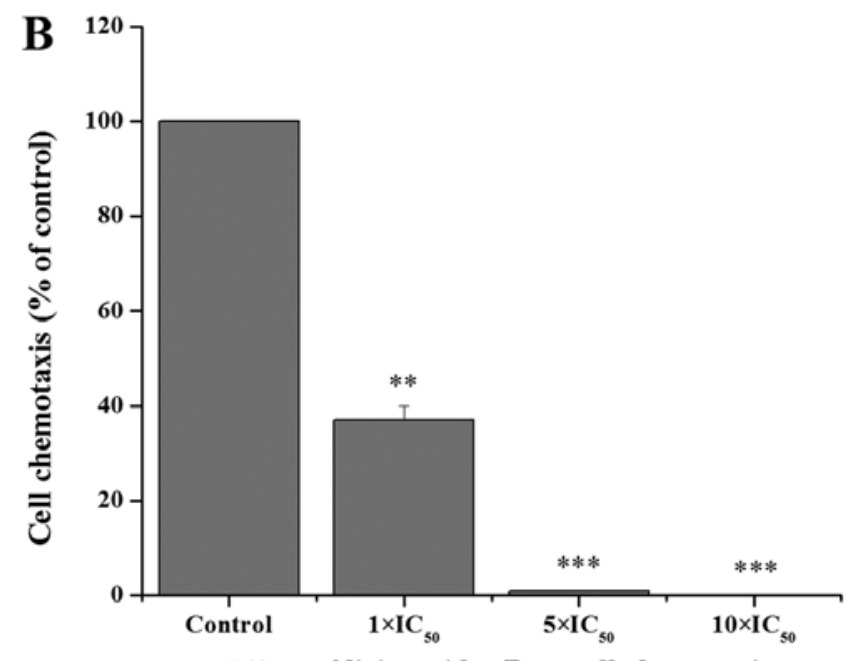

Effect of liriopesides $B$ on cell chemotaxis

Figure 3. Effect of liriopesides B on the chemotaxis of A2780 cells. In a Transwell assay, cells were treated with liriopesides B for $48 \mathrm{~h}$. (A) Representative images of chemotactic cells (magnification, $x 400$ ). (B) The chemotaxis ability was quantified by counting the cells that had transgressed through the filter in the independent experiments. All values are expressed as the mean \pm standard deviation of triplicates (one-way analysis of variance). ${ }^{* *} \mathrm{P}<0.01,{ }^{* * *} \mathrm{P}<0.001 \mathrm{vs}$. control group.

Biotechnology Co., Ltd. was added. and then incubated at $4^{\circ} \mathrm{C}$ overnight. A fully automatic chemiluminescence analyzer (Tanon-5200; Tanon Science and Technology Co., Ltd.) was used for protein visualization and semi-quantitative protein analysis (densitometry values are from chemiluminescence analyzer's software).
Statistical analysis. In the experiment, all treatments and controls were performed 3 times and values are expressed as the mean \pm standard deviation using SPSS 16.0 (SPSS, Inc.). The control and experimental groups were compared using one-way analysis of variance followed by the least-significant differences test for the quantification of the cell cycle and cell 

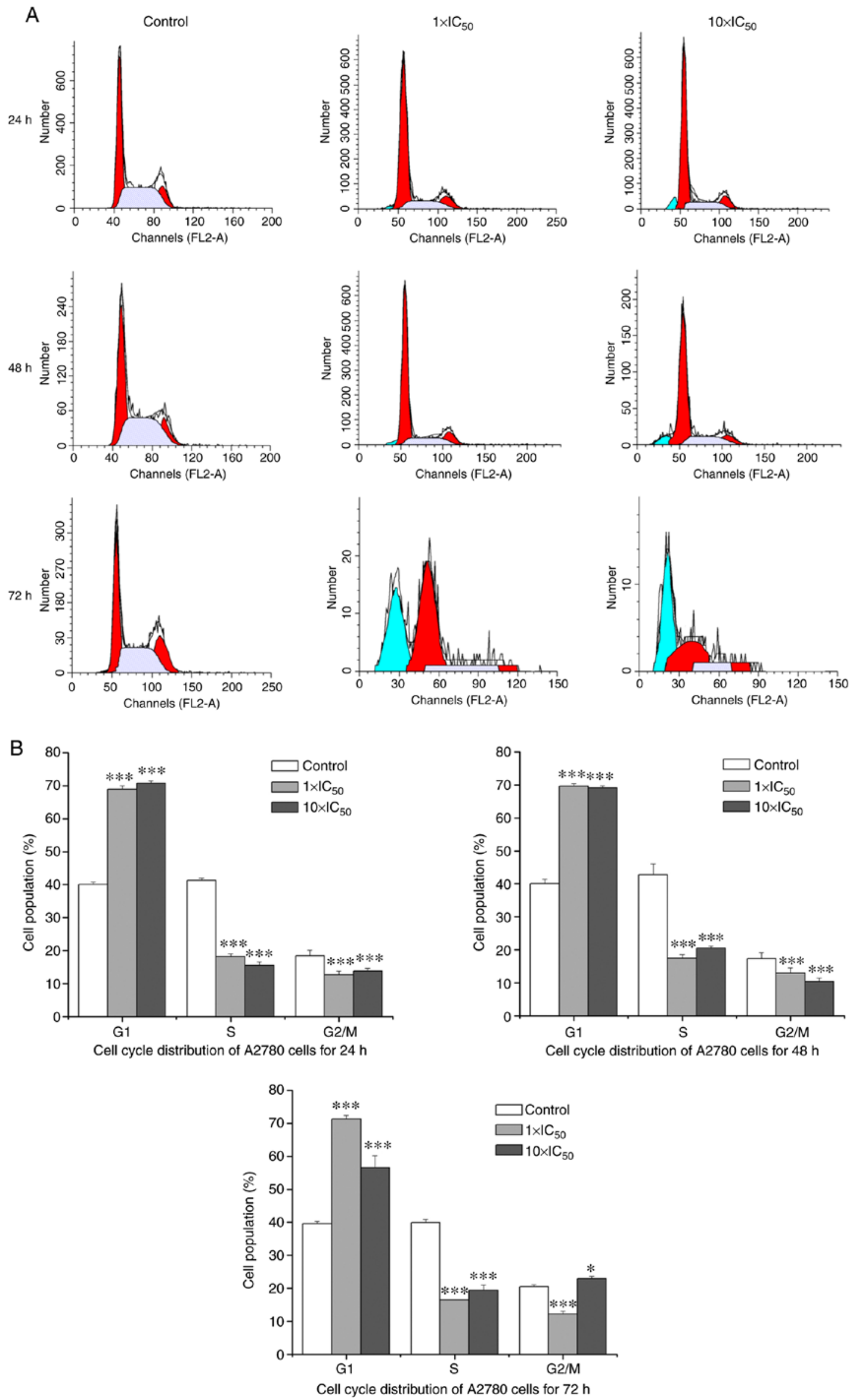

Figure 4. Cell cycle analysis of A2780 cells treated with different concentrations liriopesides B $\left(1 \mathrm{xIC}_{50}\right.$ and $\left.10 \mathrm{xIC} \mathrm{C}_{50}\right)$ for 24,48 or $72 \mathrm{~h}$ compared with each control. (A) The cell cycle distribution was determined using flow cytometry. (B) Quantification of percentages of cells in the different phases. All values are expressed as the mean \pm standard deviation of triplicates (one-way analysis of variance). ${ }^{*} \mathrm{P}<0.05,{ }^{* * * *} \mathrm{P}<0.001$ vs. control group. 

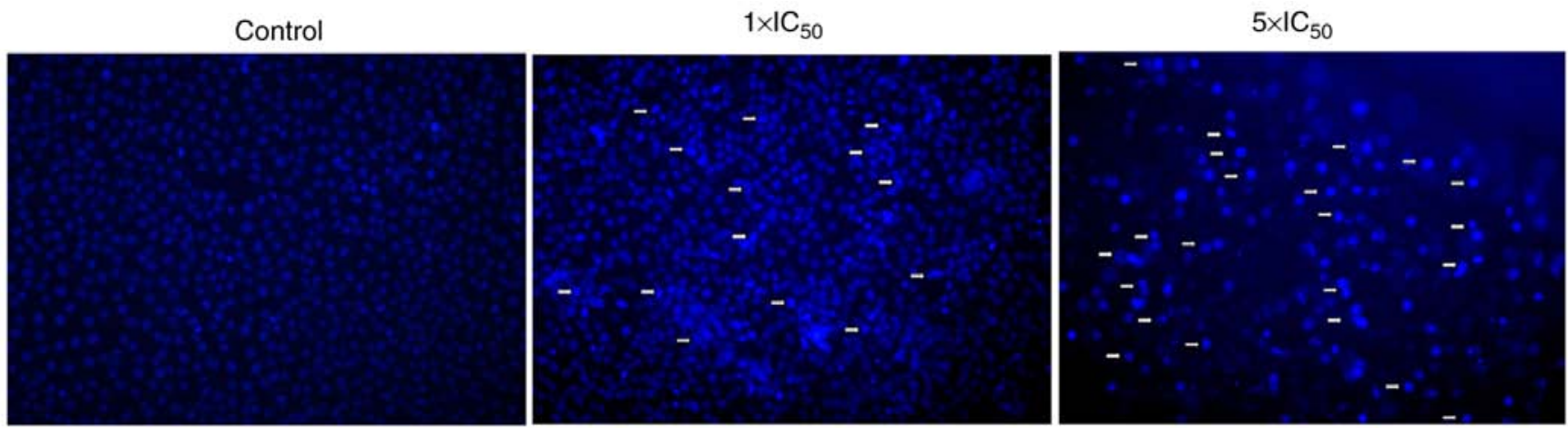

Figure 5. Effect of liriopesides B on apoptosis. In A2780 cells treated with different concentrations of liriopesides B $\left(1 \times \mathrm{xI}_{50}\right.$ and $\left.5 \times \mathrm{xIC}_{50}\right)$ for $48 \mathrm{~h}$, nuclear morphology was visualized using Hoechst 33258 staining and observed under a fluorescent microscope (magnification, x200).

apoptosis, and Dunnett's post hoc test for all other data. $\mathrm{P}<0.05$ was considered to indicate a statistically significant difference.

\section{Results}

Effect of liriopesides $B$ on invasive ability of A2780 cells. The invasive ability of cells was examined using a Transwell assay with Matrigel-coated filter membranes (Fig. 2). The results indicated that liriopesides B significantly decreased the invasive rate in a dose-dependent manner $(\mathrm{P}<0.001)$. The invasive rate was 45.316 when the concentration of liriopesides $\mathrm{B}$ was $1 \times \mathrm{XC}_{50}$ value and 1.996 at $5 \mathrm{xIC}_{50}$ value, and when the concentration of liriopesides $\mathrm{B}$ was $10 \mathrm{xIC}_{50}$ value, no invasive cells were observed.

Chemotaxis assay. The chemotactic movement ability of A2780 cells was also examined using Transwell chambers. As indicated in Fig. 3, liriopesides B significantly decreased the chemotaxis rate in a dose-dependent manner $(\mathrm{P}<0.001)$. The chemotaxis rate in the groups treated with liriopesides $\mathrm{B}$ at $1 \mathrm{xIC}_{50}, 5 \mathrm{xIC}_{50}$ and $10 \mathrm{xIC} \mathrm{IC}_{50}$ value was $37.037,0.777$ and 0 , respectively.

Cell cycle analysis. As presented in Fig. 4, different concentrations of liriopesides B significantly affected the cell cycle distribution of A2780 cells following incubation for 24, 48 and $72 \mathrm{~h}$. Of note, the maximum G1-phase percentage, $70.720 \%$, occurred after treatment with liriopesides $\mathrm{B}$ at $10 \mathrm{xIC}$. value for $24 \mathrm{~h}$, followed by 69.157 and 56.527 at 48 and $72 \mathrm{~h}$, respectively. After treatment with liriopesides $\mathrm{B}$ at $10 \mathrm{xIC} \mathrm{IC}_{50}$ value for $72 \mathrm{~h}$, the cell cycle was blocked at the $\mathrm{G} 2 / \mathrm{M}$ phase. In short, liriopesides B caused cell cycle arrest at the G1 phase after 24,48 and $72 \mathrm{~h}$, and at the G2/M phase with liriopesides B at $10 \times \mathrm{XC}_{50}$ value after $72 \mathrm{~h}$.

Hoechst 33258 assay. As illustrated in Fig. 5, Hoechst 33258 staining of A2780 cells revealed evident apoptosis bodies (the cell membrane shrinks and invaginates, divides and envelops the cytoplasm, and forms vesicular bodies containing DNA and organelles termed apoptotic bodies), condensation and margination of nuclear chromatin was present following treatment with liriopesides $\mathrm{B}$ at $5 \mathrm{xIC}_{50}$ value for $48 \mathrm{~h}$, which indicated that liriopesides B induced apoptosis in A2780 cells.
Effects of liriopesides B on early and late apoptosis. The effect of liriopesides B on early and late apoptosis of A2780 cells is illustrated in Fig. 6. Except for the proportions of early apoptosis in A2780 cells at $72 \mathrm{~h}$, a significant difference in proportions was observed in cells induced by liriopesides B in comparison with the control. The proportion of early apoptotic cells was increased to the maximum (73.645\%) following incubation with liriopesides $\mathrm{B}$ at $1 \mathrm{xIC}_{50}$ for $48 \mathrm{~h}$. As for the late apoptotic cells, they increased in a dose-dependent manner and the maximum percentage $\left(61.730 \%\right.$ at $1 \times \mathrm{IC}_{50}$ liriopesides $\mathrm{B}$ and $92.975 \%$ at $10 \times \mathrm{xC}_{50}$ liriopesides $\mathrm{B}$ ) occurred in the treatment group at $72 \mathrm{~h}$. In conclusion, liriopesides B is able to induce early and late apoptosis in A2780 cells.

$R T-q P C R$. The effects of liriopesides Bon the mRNA levels of four genes in A2780 cells are presented in Fig. 7. With the concentration of liriopesides B increasing, the expression levels of the four genes (E-CADHERIN, BCL-2,p21 and p27) were significantly affected. Specifically, E-CADHERIN, $p 21$ and $p 27$ were upregulated and $B C L-2$ was downregulated. The maximum fold change occurred in A2780 cells treated with liriopesides $\mathrm{B}$ at $10 \mathrm{xIC} \mathrm{C}_{50}$ value, there was a 253.344 -fold increase in E-CADHERIN expression, 34.303 for p21 and 8.767 for $\mathrm{p} 27$, and a minimum fold change of 0.240 for $B C L-2$ expression. In brief, liriopesides B significantly increased the expression levels of E-CADHERIN, 221 and $p 27$, whereas it decreased the expression of $B C L-2$.

Western blot analysis. Western blotting was performed to detect whether significant changes in the mRNA expression of the four genes (E-CADHERIN, BCL-2, p21 and p27) detected by RT-qPCR were consistent with the changes observed at the protein level. As indicated in Fig. 8, liriopesides B increased the levels of three proteins (E-cadherin, p21 and p27) and decreased the protein levels of Bcl-2 in A2780 cells in a dose-dependent manner. A significant difference was observed in the levels of all four proteins in A2780 cells treated with higher doses of liriopesides $\mathrm{B}\left(5 \mathrm{xIC}_{50}\right.$ and $\left.10 \mathrm{xIC} \mathrm{IC}_{50}\right)$, and the expression of E-CADHERIN was increased after treatment with all concentrations of liriopesides $B$ in the present study. As may be expected from the effects on each mRNA, liriopesides $\mathrm{B}$ had the strongest effect on E-cadherin protein levels in A2780 cells, with a maximum fold change of 1.717 at $10 \mathrm{xIC}_{50}$. Furthermore, liriopesides B also increased the protein levels 

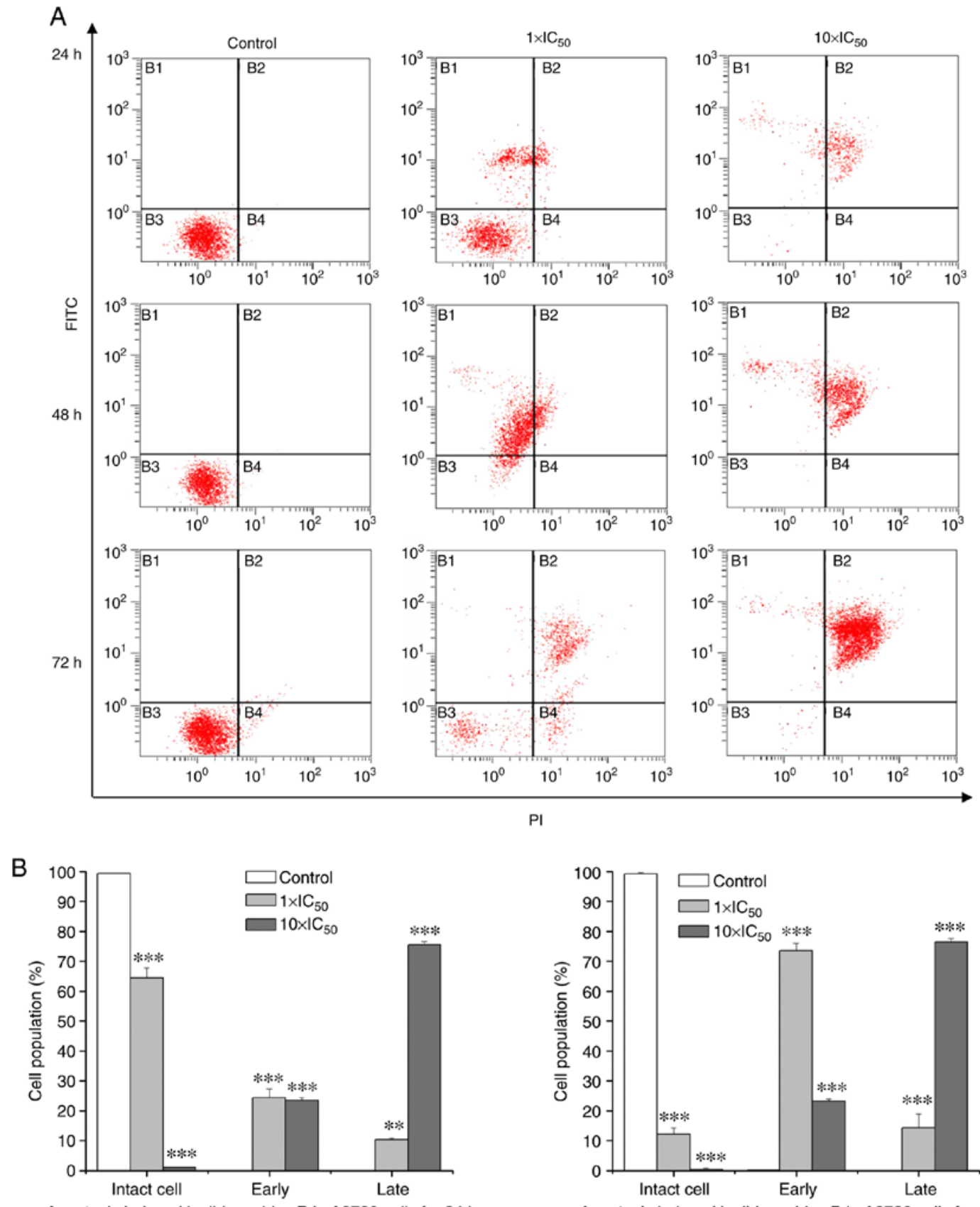

Apoptosis induced by liriopesides B in A2780 cells for $24 \mathrm{~h}$

Apoptosis induced by liriopesides B in A2780 cells for $48 \mathrm{~h}$

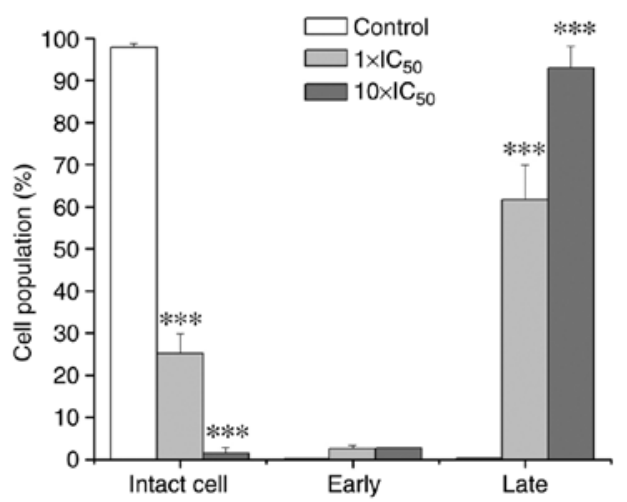

Apoptosis induced by liriopesides B in A2780 cells for $72 \mathrm{~h}$

Figure 6. Effect of liriopesides B on early and late apoptosis in A2780 cells. (A) The distribution of cells in early and late apoptosis and intact cells (non-apoptotic live cells) was determined by flow cytometry after treatment with liriopesides B for 24,48 and $72 \mathrm{~h}$ compared with each control. (B) Quantification of the cells. Early apoptosis was defined as Annexin-V FITC-positive and propidium iodide-negative cells (upper left quadrant). The double-positive group (upper right quadrant) was considered to be in late apoptosis and the double-negative group were the intact cells (lower left quadrant). All values are expressed as the mean \pm standard deviation of triplicates (one-way analysis of variance). ${ }^{* *} \mathrm{P}<0.01,{ }^{* * * *} \mathrm{P}<0.001$ vs. control group. 


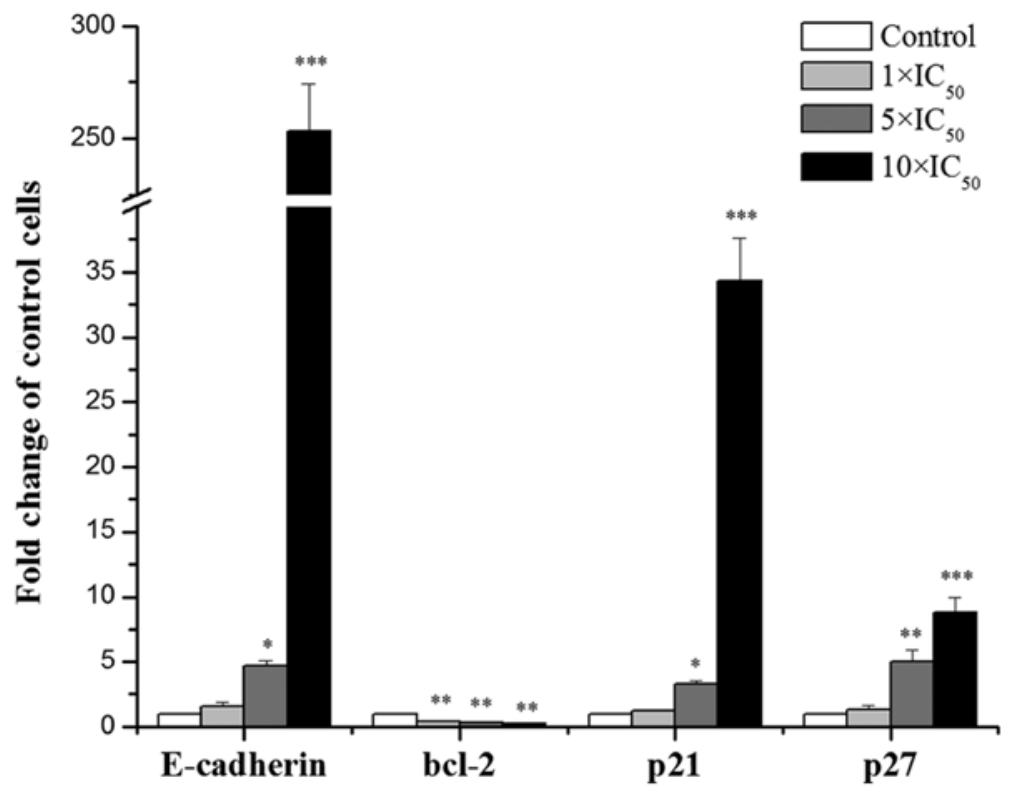

Figure 7. Expression profiles of liriopesides B-inducible genes (E-cadherin, Bcl-2, p21 and p27) in A2780 cells. Cells were treated for $48 \mathrm{~h}$ with different concentrations of liriopesides $\mathrm{B}\left(1 \times \mathrm{IC}_{50}, 5 \mathrm{xIC} \mathrm{IC}_{50}\right.$ and $\left.10 \mathrm{xIC} \mathrm{IC}_{50}\right)$. The extracted RNA was used to prepare complementary DNA that was amplified by reverse transcription-quantitative PCR to quantify the mRNA levels of each gene. Each sample was run in triplicate and the relative amount of mRNA was normalized to the GAPDH content in each sample. All values are expressed as the mean \pm standard deviation of triplicates (one-way analysis of variance). "P<0.05, ${ }^{* *} \mathrm{P}<0.01,{ }^{* * * *} \mathrm{P}<0.001$ vs. control group.
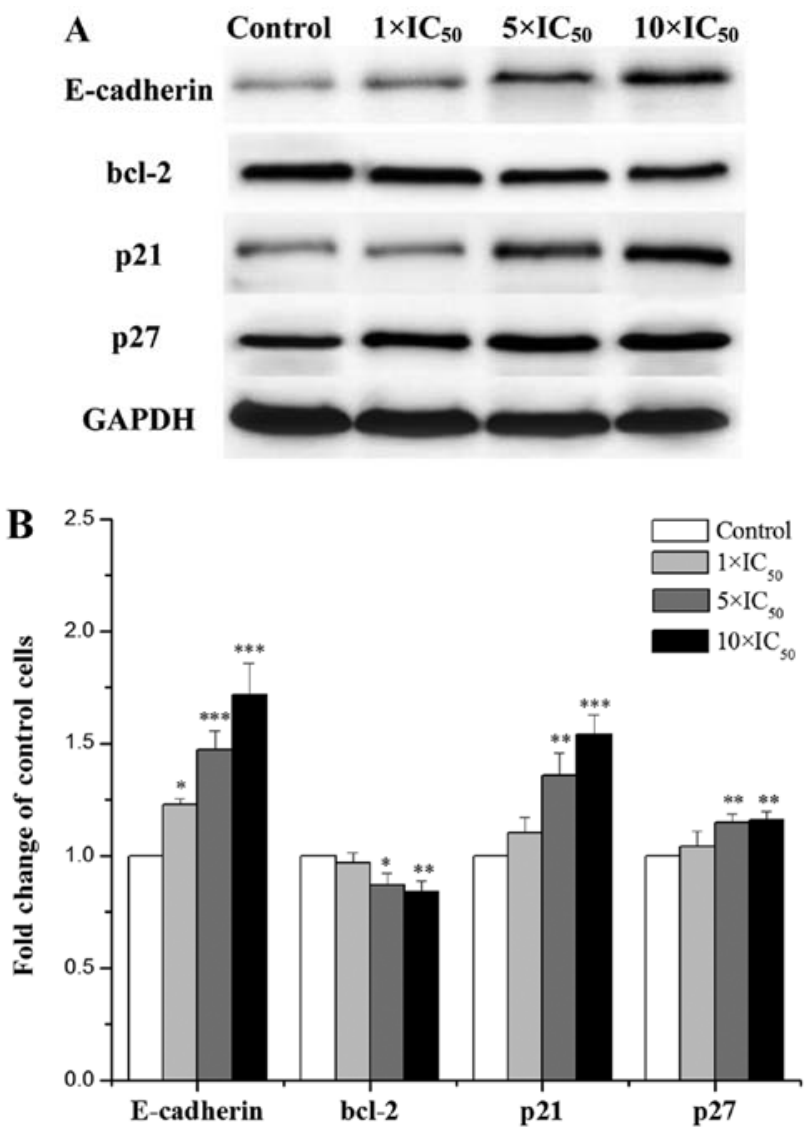

Figure 8. Western blot analysis of E-cadherin, Bcl-2, p21 and p27. A2780 cells were treated for $48 \mathrm{~h}$ with different concentrations of liriopesides $\mathrm{B}$ $\left(1 \mathrm{xIC}_{50}, 5 \mathrm{xIC}_{50}\right.$ and $\left.10 \mathrm{xIC} \mathrm{C}_{50}\right)$. (A) Protein expression was examined using western blot analysis. (B) Bar chart semi-quantifying western blot analysis, with a maximum fold change of 1.717 for E-cadherin. GAPDH was used as a loading control. All values are expressed as the mean \pm standard deviation of triplicates (one-way analysis of variance). ${ }^{*} \mathrm{P}<0.05,{ }^{* *} \mathrm{P}<0.01,{ }^{* * *} \mathrm{P}<0.001$ vs. control group. of p21 and p27, with maximum fold changes of 1.543 and 1.160 , respectively, in A2780 cells treated with the highest concentration of liriopesides B. Liriopesides B decreased protein expression of $B C L-2$, with a fold change of 0.840 . In brief, western blot analysis confirmed that the changes in protein expression levels were consistent with those in mRNA expression levels.

\section{Discussion}

Traditional Chinese Medicine provides a rich reservoir of small-molecule active components with the potential to serve as anti-cancer drugs (36). In the present study, the effects of liriopesides B on cell metastatic activity, cell cycle arrest and apoptosis of cancer cells were examined.

According to the World Health Organization, tumor cell metastasis is a major cause of death from cancer (1) and has an important role in tumor progression. The major steps of tumor development include cell adhesion, migration and invasion. E-cadherin, one of the calcium-dependent adhesion receptors, is an essential adhesive system in the epithelium for stable cell-cell adhesion (37) and may be gradually lost in advanced stages of cancer (3). Studies have indicated that E-cadherin has an important role in the progression of ovarian cancer (38-40). Insulin-like growth factor 1 is reported to induce ovarian cancer cell proliferation via downregulating E-cadherin (41). Growth differentiation factor 8 is also able to induce the migration of SKOV3 ovarian cancer cells by downregulating E-cadherin (42). Downregulation of E-cadherin expression by epidermal growth factor receptor ligand amphiregulin (AREG) induces the invasion of SKOV3 and OVCAR5 ovarian cancer cells in a SNAIL-dependent manner (43) and small interfering RNA targeting SNAIL is able to abolish AREG-induced cell invasion (44). Furthermore, 
transforming growth factor- $\alpha$ is reported to induce human ovarian cancer cell invasion by downregulating E-cadherin in a SNAIL-independent manner (45). MicroRNA-200a targeting E-cadherin repressor zinc finger E-box binding homeobox 2 is able to inhibit the migration and invasion of CD133/1+ ovarian cancer stem cells (46). Taken together, downregulation of E-cadherin may result in cancer cell proliferation, migration and invasion, while upregulation of E-cadherin may inhibit those processes associated with tumor cell metastasis. In the present study, compared with untreated cells, liriopesides B significantly suppressed A2780 cell invasion and chemotaxis in a dose-dependent manner $(\mathrm{P}<0.001)$. The results are consistent with those by Zhang et al (47). Furthermore, the gene expression levels of E-cadherin were elevated by liriopesides B in a dose-dependent manner and the maximum increase was 253.344-fold of the control group at $10 x \mathrm{IC}_{50}$ liriopesides $\mathrm{B}$. Western blot analysis also indicated that the protein expression levels of E-CADHERIN exhibited the most significant increases among the four genes selected, which was consistent with the results of the RT-qPCR analysis. In summary, liriopesides B was able to inhibit migration and invasion of A2780 cells and induce cancer cell apoptosis at least partially via upregulating $E-C A D H E R I N$. Therefore, E-cadherin may prove to be an important target in the preventative treatment of metastatic ovarian cancer (48).

The cell cycle process may be initiated via a variety of cyclin-dependent kinases (CDKs) in association with their own cyclin partners. CDK inhibitors are able to restrain the progression. CDK2, together with cyclin E, controls the G1/S-phase transition. CDK1, in association with type-A and $-\mathrm{B}$ cyclins, regulates the G2/M-phase transition. p21 and p27 are two important inhibitory proteins of the cell cycle, which are able to block cell cycle progression at the G1/S and G2/M checkpoints (49). To reveal the underlying molecular mechanisms, two important cell cycle regulatory factors, p21 and p27, were selected and changes in their expression levels were measured by RT-qPCR (50). The results indicated that liriopesides B treatment upregulated the expression levels of the two genes in a dose-dependent manner, with the maximum fold-change of control cells being 34.303 for $p 21$ and 8.767 for p27. Therefore, liriopesides B may block the cell cycle at the G1 phase via upregulating the gene expression levels of $p 21$ and $p 27$.

Apoptosis or programmed cell death, an orderly and genetically controlled form of cell death, may be initiated by a variety of extracellular stimuli, e.g., nutrition supply, DNA damage and environmental pressure (51) and is also an important mechanism of the cytotoxic effects induced by numerous anticancer drugs (52), including trans reveratorol, curcumin, isoflavones, matrine and oxymatrine. Apoptosis is distinguished from necrosis in terms of cell shrinkage and chromatin condensation, and fragmentation of nuclear components in whole apoptotic cells was clearly observed in a morphological sense without any damage to adjacent tissue (51). The efficacy of certain anticancer drugs is determined by their ability to induce tumor cells to undergo apoptosis (51). In the present study, the Hoechst 33258 assay indicated that treatment with liriopesides B for $48 \mathrm{~h}$ induced apoptosis with apparent apoptosis bodies, chromatin condensation and margination in A2780 cells. The results were confirmed by flow cytometry, which suggested that liriopesides B induced apoptosis in A2780 cells. Liriopesides $\mathrm{B}$ at $1 \mathrm{xIC}_{50}$ mainly induced early apoptosis at $24 \mathrm{~h}$ and the proportion of early apoptotic cells reached the maximum (73.6\%) at $48 \mathrm{~h}$, and subsequently, late apoptosis became prominent $(61.7 \%)$ at $72 \mathrm{~h}$. The ability to induce tumor cells to undergo apoptosis depends on the expression of various oncogenes to a large extent, including $B C L-2$, p53, $c-M Y C$, $B A X$ and $R A S$ (51). In the present study, $B C L-2$ was selected to detect changes in gene expression levels in the absence or presence of liriopesides B via RT-qPCR analysis. The results indicated a significant difference in the gene expression levels of $B C L-2$ (a multidomain anti-apoptotic Bcl-2 family member). A previous study demonstrated that liriopesides $B$ may activate Bcl-2 via upregulating p53, which initiates the intrinsic apoptotic pathway, releases cytochrome $\mathrm{C}$ from the mitochondrial membrane, activates the caspase cascade and finally leads to apoptosis in A2780 cells (52). Western blot analysis further confirmed that the changes in the protein expression levels of $B C L-2$ were consistent with the changes in its gene expression levels.

In conclusion, the present study indicated that liriopesides B may be able to suppress ovarian cancer metastasis, cause cell cycle arrest at G1 phase and induce apoptosis in A2780 cells, which may be attributed to upregulation of the expression levels of E-CADHERIN, $p 21$ and $p 27$, as well as downregulation of the expression of $B C L-2$. Therefore, liriopesides $B$ may be considered as a candidate drug against human ovarian cancer and the more detailed experiments, including clarifying the main pathway and its side effects and effectiveness in vivo, will be performed in the near future.

\section{Acknowledgements}

Not applicable.

\section{Funding}

No funding was received.

\section{Availability of data and materials}

The datasets used and/or analyzed during the current study are available from the corresponding author on reasonable request.

\section{Authors' contributions}

ZW made substantial contributions to the conception of the present study. HY and HW performed the experiments and wrote the manuscript; YY contributed to the design of the present study and interpreted the data. All authors read and approved the final version of the manuscript for publication.

\section{Ethics approval and consent to participate}

Not applicable.

\section{Patient consent for publication}

Not applicable. 


\section{Competing interests}

The authors declare that they have no competing interests.

\section{References}

1. WHO. Cancer. http://www.who.int/mediacentre/factsheets/ fs297/en/. Accessed September 12, 2018.

2. Yang ZJ, Zhao BB and Li L: The significance of the change pattern of serum CA125 level for judging prognosis and diagnosing recurrences of epithelial ovarian cancer. J Ovarian Res 9: 57, 2016.

3. Alshenawy HA: Immunohistochemical expression of epidermal growth factor receptor, E-cadherin, and matrix metalloproteinase-9 in ovarian epithelial cancer and relation to patient deaths. Ann Diagn Pathol 14: 387-395, 2010.

4. SEER Cancer Stat Facts: Ovarian Cancer. National Cancer Institute. Bethesda, MD, 2016. https://seer.cancer.gov/statfacts/ html/ovary.html.

5. Jacobs IJ, Menon U, Ryan A, Gentry-Maharaj A, Burnell M, Kalsi JK, Amso NN, Apostolidou S, Benjamin E Cruickshank D, et al: Ovarian cancer screening and mortality in the UK collaborative trial of ovarian cancer screening (UKCTOCS): A randomised controlled trial. Lancet 387 945-956, 2016.

6. Engel N, Oppermann C, Falodun A and Kragl U: Proliferative effects of five traditional Nigerian medicinal plant extracts on human breast and bone cancer cell lines. J Ethnopharmacol 137 1003-1010, 2011

7. Chinese Pharmacopoeia Commission. Pharmacopoeia of the People's Republic of China. China Medi Sci Press 26, 2015.

8. Hao LZ: The research on the chemical composition of steroidal saponins of Ophiopogonis Radix. Yanbian University, 2007.

9. Li N, Zhang L, Zeng KW, Zhou Y, Zhang JY and Che YY: Cytotoxic steroidal saponins from Ophiopogon japonicus Steroids 78: 1-7, 2013.

10. Chen M, Du Y, Qui M, Wang M, Chen K, Huang Z, Jiang M Xiong F, Chen J, Zhou J, et al: Ophiopogonin B-induced autophagy in non-small cell lung cancer cells via inhibition of the PI3K/Akt signaling pathway. Oncol Rep 29: 430-436, 2013.

11. Gao GY, Ma J, Lu P, Jiang X and Chang C: Ophiopogonin B induces the autophagy and apoptosis of colon cancer cells by activating JNK/c-Jun signaling pathway. Biomed Pharmacother 108 : 1208-1215, 2018

12. Nazim UM, Jeong JK and Park SY: Ophiopogonin B sensitizes TRAIL-induced apoptosis through activation of autophagy flux and downregulates cellular FLICE-like inhibitory protein Oncotarget 9: 4161-4172, 2017.

13. Chen M, Hu C, Guo Y, Jiang R, Jiang H, Zhou Y, Fu H, Wu M and Zhang $\mathrm{X}$ : Ophiopogonin $\mathrm{B}$ suppresses the metastasis and angiogenesis of A549 cells in vitro and in vivo by inhibiting the EphA2/Akt signaling pathway. Oncol Rep 40: 1339-1347, 2018.

14. Lee JH, Kim C, Lee SG, Sethi G and Ahn KS: Ophiopogonin D, a steroidal glycoside abrogates STAT3 signaling cascade and exhibits anti-cancer activity by causing GSH/GSSG imbalance in lung carcinoma. Cancers (Basel) 10: 427, 2018.

15. Lu Z, Wang H, Zhu M, Song W, Wang J, Wu C, Kong Y, Guo J, Li N, Liu J, et al: Ophiopogonin D', a natural product from radix ophiopogonis, induces in vitro and in vivo RIPK1-dependent and caspase-independent apoptotic death in androgen-independent human prostate cancer cells. Front Pharmacol 9: 432, 2018.

16. He J, Wei X, Li S, Quan X, Li R, Du H, Yuan S and Sun L: DT-13 suppresses breast cancer metastasis by modulating PLOD2 in the adipocytes microenvironment. Phytomedicine 59: 152778 , 2019.

17. Wei X, Mao T, Li S, He J, Hou X, Li H, Zhan M, Yang X, Li R Xiao J, et al: DT-13 inhibited the proliferation of colorectal cancer via glycolytic metabolism and AMPK/mTOR signaling pathway. Phytomedicine 54: 120-131, 2019.

18. Wang Z, Wang Y, Zhu S, Liu Y, Peng X, Zhang S, Zhang Z, Qiu Y, Jin M, Wang R, et al: DT-13 inhibits proliferation and metastasis of human prostate cancer cells through blocking PI3K/Akt pathway. Front Pharmacol 9: 1450, 2018.

19. Li H, Sun L, de Carvalho EL, Li X, Lv X, Khan GJ, Semukunzi H, Yuan S and Lin S: DT-13, a saponin monomer of dwarf lilyturf tuber, induces autophagy and potentiates anti-cancer effect of nutrient deprivation. Eur J Pharmacol 781: 164-172, 2016
20. Zhang Y, Liu J, Kou J, Yu J and Yu B: DT-13 suppresses MDA-MB-435 cell adhesion and invasion by inhibiting MMP-2/9 via the p38 MAPK pathway. Mol Med Rep 6: 1121-1125, 2012

21. Ren-Ping Z, Sen-Sen L, Yuan ST, Yu BY, Bai XS, Sun L and Zhang LY: DT-13, a saponin of dwarf lilyturf tuber, exhibits anti-cancer activity by down-regulating C-C chemokine receptor type 5 and vascular endothelial growth factor in MDA-MB-435 cells. Chin J Nat Med 12: 24-29, 2014.

22. Lin SS, Fan W, Sun L, Li FF, Zhao RP, Zhang LY, Yu BY and Yuan ST: The saponin DT-13 inhibits gastric cancer cell migration through down-regulation of CCR5-CCL5 axis. Chin J Nat Med 12: 833-840, 2014

23. Wei XH, Lin SS, Liu Y, Zhao RP, Khan GJ, Du HZ, Mao TT, Yu BY, Li RM, Yuan ST and Sun L: DT-13 attenuates human lung cancer metastasis via regulating NMIIA activity under hypoxia condition. Oncol Rep 36: 991-999, 2016.

24. Du H, Liu Y, Chen X, Yu X, Hou X, Li H, Zhan M, Lin S, Lu L Yuan S and Sun L: DT-13 synergistically potentiates the sensitivity of gastric cancer cells to topotecan via cell cycle arrest in vitro and in vivo. Eur J Pharmacol 818: 124-131, 2018.

25. Yu XW, Lin S, Du HZ, Zhao RP, Feng SY, Yu BY, Zhang LY, Li RM, Qian CM, Luo XJ, et al: Synergistic combination of DT-13 and topotecan inhibits human gastric cancer via myosin IIA-induced endocytosis of EGF receptor in vitro and in vivo. Oncotarget 7: 32990-33003, 2016.

26. Yu XW, Wei D, Gao YS, Du HZ, Yu BY, Li RM, Qian CM, Luo XJ, Yuan ST, Wang JS and Sun L: Synergistic combination of DT-13 and topotecan inhibits aerobic glycolysis in human gastric carcinoma BGC-823 cells via NM IIA/EGFR/HK II axis. J Cell Mol Med 23: 6622-6634, 2019.

27. Li H, Sun L, Li H, Lv X, Semukunzi H, Li R, Yu J, Yuan S and Lin S: DT-13 synergistically enhanced vinorelbine-mediated mitotic arrest through inhibition of FOXM1-BICD2 axis in non-small-cell lung cancer cells. Cell Death Dis 8: e2810, 2017.

28. Li H, Sun L, Li H, Lv X, Semukunzi H, Li R, Yu J, Yuan S and Lin S: DT-13, a saponin monomer 13 of the Dwarf lilyturf tuber, synergized with vinorelbine to induce mitotic arrest via activation of ERK signaling pathway in NCI-H1299 cells. Biomed Pharmacother 89: 1277-1285, 2017.

29. Wang H, Yu H, Sun Y, Zhao H, Guo Z and Yu B: Liriopesides B inhibited cell growth and decreased CA125 level in human ovarian cancer A2780 cells. Nat Prod Res 31: 2198-2202, 2017.

30. Nizamutdinova IT, Lee GW, Lee JS, Cho MK, Son KH, Jeon SJ, Kang SS, Kim YS, Lee JH, Seo HG, et al: Tanshinone I suppresses growth and invasion of human breast cancer cells, MDA-MB-231, through regulation of adhesion molecules. Carcinogenesis 29: 1885-1892, 2008.

31. Yang CX, Liu SY, San JH and Yang M: Matrine suppresses proliferation of Raji cells via inhibition of notch signaling pathway. Chin J Biologicals 30: 1162-1167, 2017.

32. Wang H, Ao M, Wu J and Yu L: TNFa and Fas/FasL pathways are involved in 9-methoxycamptothecin-induced apoptosis in cancer cells with oxidative stress and G2/M cell cycle arrest. Food Chem Toxicol 55: 396-410, 2013.

33. Livak KJ and Schmittgen TD: Analysis of relative gene expression data using real-time quantitative PCR and the 2(-Delta Delta C(T)) method. Methods 25: 402-408, 2001.

34. Jiang N, Zhou LQ and Zhang XY: Downregulation of the nucleosome-binding protein 1 (NSBP1) gene can inhibit the in vitro and in vivo proliferation of prostate cancer cells. Asian J Androl 12: 709-717, 2010

35. Sun P, Jin J, Wang Y, Ren X, Chen L, Lin Z and Piao Y: Baicalein induces the apoptosis of gastric cancer MGC-803 cells. Tumor 37 1041-1046, 2017.

36. Tan W, Lu J, Huang M, Li Y, Chen M, Wu G, Gong J, Zhong Z, $\mathrm{Xu} \mathrm{Z}$, Dang Y, et al: Anti-cancer natural products isolated from chinese medicinal herbs. Chin Med 6: 27, 2011.

37. Braga V: Spatial integration of E-cadherin adhesion, signalling and the epithelial cytoskeleton. Curr Opin Cell Biol 42: 138-145, 2016.

38. Li Y, Liang J, Kang S, Dong Z, Wang N, Xing H, Zhou R, Li X and Zhao X: E-cadherin gene polymorphisms and haplotype associated with the occurrence of epithelial ovarian cancer in Chinese. Gynecol Oncol 108: 409-414, 2008.

39. Cheng JC, Chang HM, Xiong S, So WK and Leung PC: Sprouty2 inhibits amphiregulin-induced down-regulation of E-cadherin and cell invasion in human ovarian cancer cells. Oncotarget 7: 81645-81660, 2016. 
40. Zhang Y, Fan N and Yang J: Expression and clinical significance of hypoxia-inducible factor $1 \alpha$, Snail and E-cadherin in human ovarian cancer cell lines. Mol Med Rep 12: 3393-3399, 2015.

41. Lau MT and Leung PC: The PI3K/Akt/mTOR signaling pathway mediates insulin-like growth factor 1-induced E-cadherin down-regulation and cell proliferation in ovarian cancer cells. Cancer Lett 326: 191-198, 2012.

42. Zhao J, Klausen C, Xiong S, Cheng JC, Chang HM and Leung PC: Growth differentiation factor 8 induces SKOV3 ovarian cancer cell migration and E-cadherin down-regulation. Cell Signal 28: 1615-1622, 2016.

43. Cheng JC, Qiu X, Chang HM and Leung PC: HER2 mediates epidermal growth factor-induced down-regulation of E-cadherin in human ovarian cancer cells. Biochem Biophys Res Commun 434: 81-86, 2013.

44. So WK, Fan Q, Lau MT, Qiu X, Cheng JC and Leung PC: Amphiregulin induces human ovarian cancer cell invasion by down-regulating E-cadherin expression. FEBS Lett 588 3998-4007, 2014.

45. Qiu X, Cheng JC, Klausen C, Fan Q, Chang HM, So WK and Leung PC: Transforming growth factor- $\alpha$ induces human ovarian cancer cell invasion by down-regulating E-cadherin in a Snail-independent manner. Biochem Biophys Res Commun 461: 128-135, 2015.

46. Wu Q, Guo R, Lin M, Zhou B and Wang Y: MicroRNA-200a inhibits CD133/1+ ovarian cancer stem cells migration and invasion by targeting E-cadherin repressor ZEB2. Gynecol Oncol 122: 149-154, 2011.
47. Zhang Y, Han Y, Zhai K, Sun M, Liu J, Yu B and Kou J: Ophiopogonin-D suppresses MDA-MB-435 cell adhesion and invasion by inhibiting matrix metalloproteinase-9. Mol Med Rep 12: 1493-1498, 2015.

48. Ansenberger K, Zhuge Y, Lagman JA, Richards C, Barua A, Bahr JM and Hales DB: E-cadherin expression in ovarian cancer in the laying hen, gallus domesticus, compared to human ovarian cancer. Gynecol Oncol 113: 362-369, 2009.

49. Harada $\mathrm{K}$ and Ogden GR: An overview of the cell cycle arrest protein, p21(WAF1). Oral Oncol 36: 3-7, 2000.

50. Sørby LA, Andersen SN, Bukholm IR and Jacobsen MB: Evaluation of suitable reference genes for normalization of real-time reverse transcription PCR analysis in colon cancer. J Exp Clin Cancer Res 29: 144, 2010.

51. Guchelaar HJ, Vermes A, Vermes I and Haanen C: Apoptosis: Molecular mechanisms and implications for cancer chemotherapy. Pharm World Sci 19: 119-125, 1997.

52. Kim R, Tanabe K, Uchida Y, Emi M, Inoue H and Toge T: Current status of the molecular mechanisms of anticancer drug-induced apoptosis. The contribution of molecular-level analysis to cancer chemotherapy. Cancer Chemother Pharmacol 50: 343-352, 2002.

c) (i) (9) This work is licensed under a Creative Commons

EY No ND Attribution-NonCommercial-NoDerivatives 4.0 International (CC BY-NC-ND 4.0) License. 